\title{
Invited review: Incidence, risk factors, and effects of clinical mastitis recurrence in dairy cows
}

\author{
Hossein Jamali, ${ }^{\star} \dagger$ Herman W. Barkema, ${ }^{\ddagger} \ddagger$ Mario Jacques, ${ }^{*} \dagger$ Eve-Marie Lavallée-Bourget, ${ }^{\star} \dagger$ \\ François Malouin, ${ }^{*} \S$ Vineet Saini, ${ }^{*} \ddagger$ Henrik Stryhn, ${ }^{*} \#$ and Simon Dufour ${ }^{*}{ }^{1}$ \\ ${ }^{*}$ Canadian Bovine Mastitis and Milk Quality Research Network, C.P. 5000, St-Hyacinthe, Québec, Canada J2S 2M2 \\ †Département de Pathologie et Microbiologie, Faculté de Médecine Vétérinaire, Université de Montréal, C.P. 5000, St-Hyacinthe, Québec, \\ Canada J2S 7C6 \\ łDepartment of Production Animal Health, Faculty of Veterinary Medicine, University of Calgary, Calgary, Alberta, Canada T2N 4N1 \\ §Département de Biologie, Faculté des Sciences, Université de Sherbrooke, Sherbrooke, Québec, Canada J1K 2R1 \\ \#Department of Health Management, Atlantic Veterinary College, University of Prince Edward Island, Charlottetown, Canada C1A 4P3
}

\section{ABSTRACT}

Clinical mastitis $(\mathrm{CM})$ is one of the most frequent and costly diseases in dairy cows. A frustrating aspect of CM is its recurrent nature. This review was conducted to synthesize knowledge on risk of repeated cases of CM, effects of recurrent $\mathrm{CM}$ cases, and risk factors for $\mathrm{CM}$ recurrence. A systematic review methodology was used to identify articles for this narrative review. Searches were performed to identify relevant scientific literature published after 1989 in English or French from 2 databases (PubMed and CAB Abstracts) and 1 search platform (Web of Science). Fifty-seven manuscripts were selected for qualitative synthesis according to the inclusion criteria. Among the 57 manuscripts selected in this review, a description of CM recurrence, its risk factors, and effects were investigated and reported in 33, 37, and 19 selected manuscripts, respectively. Meta-analysis and meta-regression analyses were used to compute risk ratio comparing risk of $\mathrm{CM}$ in cows that already had 1 $\mathrm{CM}$ event in the current lactation with risk of $\mathrm{CM}$ in healthy cows. For these analyses, 9 manuscripts that reported the total number of lactations followed and the number of lactations with $\leq 1$ and $\leq 2 \mathrm{CM}$ cases were used. When summarizing results from studies requiring $\geq 5 \mathrm{~d}$ between $\mathrm{CM}$ events to consider a $\mathrm{CM}$ event as a new case, we observed no significant change in CM susceptibility following a first CM case (risk ratio: 0.99; 95\% confidence interval: 0.86-1.14). However, for studies using a more liberal CM recurrence definition (i.e., only $24 \mathrm{~h}$ between $\mathrm{CM}$ events to consider new CM cases), we observed a 1.54 times greater CM risk (95\% confidence interval: 1.20-1.97) for cows that already had $1 \mathrm{CM}$ event in the current lactation compared with

Received August 22, 2017.

Accepted January 19, 2018.

${ }^{1}$ Corresponding author: simon.dufour@umontreal.ca healthy cows. The most important risk factors for CM recurrence were parity (i.e., higher risk in older cows), a higher milk production, pathogen species involved in the preceding case, and whether a bacteriological cure was observed following the preceding case. The most important effects of recurrent CM were the milk yield reduction following a recurrent $\mathrm{CM}$ case, which was reported to be similar to that of the first CM case, and the increased risk of culling and mortality, which were reported to surpass those of first CM cases.

Key words: dairy cow, clinical mastitis, recurrence, meta-analysis

\section{INTRODUCTION}

Clinical mastitis (CM) is one of the most frequent diseases affecting dairy cows worldwide (Barnouin et al., 1999; Ruegg, 2003; Halasa et al., 2007). The incidence rate of $\mathrm{CM}$ ranges from 13 to 40 cases/100 cow years in different countries and housing types (Peeler et al., 2002; McDougall et al., 2007; Bar et al., 2008b; Olde Riekerink et al., 2008; van den Borne et al., 2010).

The effect of CM was investigated in numerous studies. Negative effects include severe milk losses (Gröhn et al., 2004; Steeneveld et al., 2008; Schukken et al., 2009), decreased milk quality (Barbano et al., 2006), increased treatment costs (Bar et al., 2008b), veterinary costs, extra labor (Pérez-Cabal et al., 2009), and increased probability of death and culling of the affected dairy cows (Bar et al., 2008b; Hertl et al., 2011; Cha et al., 2013). Clinical mastitis is also the main reason for antimicrobial use on dairy farms, although antimicrobial therapy is not required in all cases of $\mathrm{CM}$ ( $\mathrm{Pol}$ and Ruegg, 2007; Hill et al., 2009; Lago et al., 2011a; Saini et al., 2012). The average cost of $\mathrm{CM}$ was estimated at $€ 112$ to $€ 1,006$ per CM case in Finland (Heikkilä et al., 2012), US $\$ 95$ to $\$ 211$ in the United States (Cha et al., 2011), and Can $\$ 744$ in Canada (M. Aghamohammadi, 
University of Montreal; Denis Haine, University of Montreal; D. F. Kelton, University of Guelph, Guelph, ON, Canada; H. Hogeveen, Wageningen University and Research Center, Wageningen, the Netherlands; G. P. Keefe, University of Prince Edward Island; unpublished data).

Many studies investigated risk factors for $\mathrm{CM}$ as well as for CM recurrence. Parity (i.e., older cows) and the early lactation period are important risk factors for CM (Hertl et al., 2011; Elghafghuf et al., 2014). During the first $30 \mathrm{DIM}$, the incidence rate of $\mathrm{CM}$ was estimated to be 4.6 and 2.0 times higher than during the remaining lactation in multiparous and primiparous cows, respectively (van den Borne et al., 2010; Hammer et al., 2012). Relatively high herd SCS (Nash et al., 2000; Wolf et al., 2010; Elghafghuf et al., 2014), teat-end callosity (Neijenhuis et al., 2001; Zadoks et al., 2001), tramped teats, and milk leakage (Elbers et al., 1998) were also identified as risk factors for $\mathrm{CM}$ in previous studies.

A very frustrating aspect of $\mathrm{CM}$ is its recurrent nature. A high proportion of cows experiencing a $\mathrm{CM}$ event in a lactation will experience additional CM episodes during the same lactation (Schukken et al., 2010). It has been observed that cows that already experienced CM, irrespective of the pathogen involved, are more prone to develop new IMI (Zadoks et al., 2001). Recurrence of CM, however, may also be caused by persistent IMI. After an apparently resolved CM case, the IMI may persist despite resolution of the clinical signs, and subsequent CM flare-up may be observed (Döpfer et al., 1999). Some pathogens are more likely to cause recurrent CM events after a first CM episode (Döpfer et al., 1999; Bradley and Green, 2001a; Zadoks et al., 2003). For example, high CM recurrence rates were observed following Escherichia coli and Streptococcus uberis CM (Döpfer et al., 1999; Zadoks et al., 2003). Whether this is due to an increased cow susceptibility to new infection or to IMI persistency between CM cases is unclear. Furthermore, intracellular survival of Staphylococcus aureus can lead to subsequent CM episodes (Yancey et al., 1991). In such cases, CM recurrence is, therefore, likely to result mainly from persistence of the pathogen in the udder (Yancey et al., 1991; Wenz et al., 2005; Swinkels et al., 2013; Abureema et al., 2014).

Many studies conducted in various countries have described the incidence rate of CM and its estimated effects and risk factors; however, there are fewer reports on CM recurrence. For instance, it is still unclear whether the hazard of experiencing a second CM case is increased, maintained, or reduced when compared with the baseline CM risk. Similarly, only a few studies have investigated the effect (e.g., milk yield reduction, mortality, or culling risk) of subsequent $\mathrm{CM}$ cases after a first CM case in the lactation. Finally, although various hypotheses have been proposed, the interplay of the cow, pathogen, and environment factors that lead to disease recurrence is yet unclear. A first objective of the current review was therefore to synthesize knowledge on risk of additional $\mathrm{CM}$ events following a first $\mathrm{CM}$ case using a systematic review and meta-analysis study design. Secondary objectives were to report in a narrative review format on effects of recurrent $\mathrm{CM}$ events and on risk factors for CM recurrence in dairy cows.

\section{MATERIALS AND METHODS}

The selected study design was a narrative review of the literature; however, we made use of the systematic review methodology for selecting articles and for the meta-analysis. The Preferred Reporting Items for Systematic Reviews and Meta-Analyses (PRISMA) methodology was used as a guideline during the research process and while writing this manuscript (Moher et al., 2009).

\section{Research Questions}

Three objectives - describing the risk of CM recurrence, effects of recurrent $\mathrm{CM}$ events, and risk factors for CM recurrence - were pursued. These 3 objectives were described separately in the 3 following research questions:

1. What is the risk of recurrence of $\mathrm{CM}$ in a given lactation in dairy cows?

2. What are the effects of recurrent $\mathrm{CM}$ in dairy cows?

3. What are the risk factors that influence CM recurrence in dairy cows?

\section{Literature Search and Inclusion Criteria}

Two databases (CAB Abstracts and PubMed) and 1 search platform (Web of Science) were used to search for English or French original manuscripts on May 7, 2014. To ensure that the information was relevant for contemporary dairy herds, only manuscripts published after 1989 were included. A single search strategy for the 3 research questions but specific to each database was designed with the assistance of a librarian. The strategy consisted of Boolean search operators combining medical subject heading or thesaurus terms. The search terms described (1) the population of interest (dairy cows), (2) the outcome (CM), and (3) the recurrent aspect of the disease. The complete search strategies can be found in Supplemental File S1 (https://doi .org/10.3168/jds.2017-13730). 
All references obtained using the 3 electronic searches were imported in EndNote X7.1; electronic searches were merged and duplicates were eliminated. Only those references for which at least an abstract was available were further evaluated. Articles from conference proceedings and other gray literature were not excluded. To ensure a minimal level of proof and to ensure that the results were relevant for modern commercial dairies, the following criteria were defined for inclusion and exclusion of a manuscript:

1. The manuscript was complete, presented original analyses, and described recurrence of $\mathrm{CM}$, its risk factors, or effects.

2. The research investigated naturally occurring CM (i.e., studies involving experimentally induced CM were excluded).

3. The study design was not a case report, case series, or expert opinion.

4. The study did not involve tropical breeds (e.g., buffaloes and Gyr cows).

5. The study was conducted in contemporary commercial dairies (i.e., studies conducted on smallholder dairy farms practicing subsistence farming were excluded).

If the information regarding inclusion criteria or results reported was incomplete, the authors of the manuscripts were contacted by email and asked to provide the information needed. The titles and abstracts of all the manuscripts obtained were compiled. Reviewers were blind to the authors, journal, and year of publication. Three reviewers (S. D., H. J., and E.-M. L. B.) independently read the abstracts. Each reviewer decided individually on the relevance of the study while taking into account the inclusion criteria. At this stage, reviewers were less strict on the inclusion criteria to avoid eliminating any relevant study. Whenever the 3 reviewers disagreed on the selection of an abstract, they consulted each other and discussed the relevance of the abstract for deciding on eligibility. Then, if at least 2 authors decided to keep the abstract, it was selected for the next step. After the preliminary selection of the abstracts, the full text of each selected manuscript was read by 3 reviewers (S. D., H. J., and E.-M. L. B.). Inclusion criteria were then strictly applied to select full texts for inclusion in the review.

The list of references of each included manuscript was then screened and relevant references that were not identified during the initial database search were investigated (i.e., review of abstract and then full text as previously described). Furthermore, manuscripts citing the included manuscripts were identified using
Web of Science. Abstracts and then full texts of these manuscripts were reviewed as well. Whenever screening of references or search for manuscripts citing included manuscripts resulted in the inclusion of an additional study, a new iteration of reference screening and search for citing manuscripts was undertaken until complete depletion. The last search on Web of Science for manuscripts citing the included texts was conducted on October 21, 2014, for all included texts.

\section{Data Extraction}

Two authors (S. D. and H. J.) analyzed the included manuscripts in parallel and abstracted the following information in an Excel database: study location and period; study design; number of herds, cows, and lactations followed; follow-up duration (i.e., multiple lactations, single but complete lactation, or number of days following a first CM case); and data presented (number of cow lactations followed, number of cow lactations with 1 single CM event, number of cow lactations with $2 \mathrm{CM}$ events, number of cow lactations with $>2 \mathrm{CM}$ events, risk factors for CM recurrence, or effects of recurrent $\mathrm{CM}$ ).

\section{Meta-Analysis and Quantitative Synthesis}

A meta-analysis was conducted to describe risk of CM recurrence. For this analysis, only those manuscripts from which the authors of the review could extract the total number of lactations followed and the number of lactations with $\geq 1$ and $\geq 2 \mathrm{CM}$ events were included. Manuscripts in which cows were not followed for their complete lactation were excluded because data for number of lactations with a specific number of CM cases could not be extracted from these manuscripts. Furthermore, manuscripts reporting the needed data, but only for a subset of dairy cows, were excluded because including them would have made the computation of a summary measure irrelevant. For instance, 2 manuscripts (Heringstad et al., 2006; Vazquez et al., 2009) reporting the needed data, but for first-lactation cows only, were excluded. Whenever the needed data were reported for a given study in more than 1 manuscript, only the manuscript presenting results for the largest data set was included. Data were also extracted for 2 important study characteristics hypothesized to be a source of heterogeneity between studies: (1) source of data used in each study (i.e., data collected specifically for the study vs. use of an existing database such as data from dairy management software or from a national animal health database) and (2) CM recurrence case definition, with the main difference between 
studies being the minimal number of days (i.e., the lag time) between $2 \mathrm{CM}$ episodes to consider $\mathrm{CM}$ cases as 2 independent cases (vs. 1 single maintained CM event).

Meta-analysis was performed using Review Manager (RevMan version 5.3.5; The Cochrane Collaboration, The Nordic Cochrane Centre, Copenhagen, Denmark). To describe risk of $\mathrm{CM}$ recurrence, for each study, risk ratio (RR) with $95 \%$ confidence intervals (CI) comparing risk of subsequent $\mathrm{CM}$ cases in cows having experienced a case in the current lactation $\left(\mathrm{R}_{\mathrm{CM}}\right)$ with that of healthy cows $\left(\mathrm{R}_{\text {healthy }}\right)$ was computed. An $\mathrm{RR}$ $<1.0$ could, therefore, be interpreted as a reduced risk of $\mathrm{CM}$ following a first $\mathrm{CM}$ case, $\mathrm{RR}$ of 1.0 as an equal maintained risk, and a $\mathrm{RR}>1.0$ as an increased risk of CM following a first CM case. Equations 1, 2, and 3 illustrate computation of the RR from each study.

$$
\begin{gathered}
\mathrm{R}_{\mathrm{CM}}=\frac{\text { no. of lactations with } \geq 2 \mathrm{CM} \text { episodes }}{\text { no. of lactations with } \geq 1 \mathrm{CM} \text { episode }} \\
\mathrm{R}_{\text {healthy }}=\frac{\text { no. of lactations with } \geq 2 \mathrm{CM} \text { episodes }}{\text { no. of lactations followed }} \\
\mathrm{RR}=\frac{\mathrm{R}_{\mathrm{CM}}}{\mathrm{R}_{\text {healthy }}}
\end{gathered}
$$

A random effect model was used to compute a summary of effect across studies. Given the range of years and countries covered by the review and the nature of the studies, assuming a single common RR appeared untenable, hence the choice of the more conservative random effect model. Heterogeneity between studies was assessed using the $\mathrm{I}^{2}$ statistic (Higgins and Green, 2011). Putative sources of heterogeneity (i.e., source of data used and CM recurrence case definition) were investigated using subgroup analyses and univariate meta-regression. Meta-regression was conducted using PROC MIXED of SAS 9.4 (SAS Institute Inc., Cary, NC) as described by van Houwelingen et al. (2002). The model was as follows:

$$
\log (\mathrm{RR})=\beta_{0}+\beta_{1} X_{i}+e_{i}+u_{i},
$$

where $\log (R R)$ is $R R$ natural logarithm; $\beta_{0}$ is the intercept representing the mean $\log (\mathrm{RR})$ when a given study characteristic is absent; $\beta_{1}$ is the effect of a given study characteristic on $\mathrm{RR}$ natural logarithm; $e_{i}$ is the within-study variance; and $u_{i}$ is the study random intercept representing the between-studies variance. Influence of each study was then investigated by deleting each study from the meta-analysis and determining the change in the overall and subgroup summaries of effect as proposed by O'Connor et al. (2014).
All studies included in the quantitative synthesis were observational studies aiming to describe CM in general or investigating CM risk factors or consequences. Furthermore, in most manuscripts, the data required for the quantitative synthesis were presented as descriptive materials and, in many cases, CM recurrence was not the scope of the included manuscript. Compared with intervention studies, the risk of publication bias (e.g., underreporting of studies showing no effect) therefore appears to be very low. Nevertheless, a funnel plot was sketched to investigate presence of a publication bias.

The Newcastle-Ottawa Scale (NOS) for assessing the quality of nonrandomized studies was used to assess risk of bias for the studies included in the meta-analysis (Wells et al., 2014). The NOS tool was developed to judge studies using cohort or case-control study design on 8 items categorized in 3 categories: (1) selection of the study groups, (2) comparability of the groups, and (3) ascertainment of exposure (case-control studies) or outcome (cohort studies) of interest. The objective of the meta-analysis was simply to report and compare risk of first and second $\mathrm{CM}$ events, not to report on effect of a given exposure on risk of acquiring a disease. Therefore, the NOS items on ascertainment of exposure, on demonstration that the outcome is absent at the start of the study, and on comparability of the groups (i.e., confounding bias) did not apply and were not evaluated. The minimal follow-up period during which outcome occurrence had to be observed was defined as the complete lactation.

\section{RESULTS AND DISCUSSION}

A flow chart describing flow of information through the different phases of the review is presented in Figure 1. A total of 1,465 abstracts were retrieved from CAB Abstracts (559 abstracts), Web of Science (557 abstracts), and PubMed (349 abstracts). After removal of duplicates, there were 782 unique abstracts. Among these, 45 articles met the selection criteria for inclusion in the systematic review. Then, 118 and 766 additional manuscripts were identified by reference screening and searching for manuscripts that cited retained manuscripts, respectively. A total of 12 additional manuscripts were included, and therefore 57 manuscripts were selected according to the inclusion and exclusion criteria (Figure 1). Description of CM recurrence, CM risk factors, and CM effects were studied and reported in 33,37 , and 19 manuscripts, respectively (Table 1; Figure 2).

During the process of reviewing the full texts, in one of the selected manuscripts (Friedman et al., 2004) we observed important contradictions between text and tables regarding the results of interest for the cur- 
rent review. Because exact information could not be confirmed after multiple attempts to contact the authors, this manuscript was excluded. For 8 manuscripts (Vaarst and Enevoldsen, 1997; Sviland and Waage, 2002; Gasqui et al., 2003; Heringstad et al., 2006; Wolfová et al., 2006; Wolf et al., 2010; Heravi Moussavi et al., 2012; Oliveira et al., 2013), ancillary information regarding $\mathrm{CM}$ description (e.g., number of cow lactations or cow days followed) was missing. Authors of the 8 manuscripts were contacted and asked to provide the needed information; this information was obtained for 3 manuscripts (Sviland and Waage, 2002; Gasqui et al., 2003; Heringstad et al., 2006) and was not available for 1 manuscript (Oliveira et al., 2013), and an answer from the authors could not be obtained for 4 manuscripts (Vaarst et al., 2002; Wolfová et al., 2006; Wolf et al., 2010; Heravi Moussavi et al., 2012).

Abstracts and manuscripts in Persian $(\mathrm{n}=1)$, Portuguese $(\mathrm{n}=1)$, Dutch $(\mathrm{n}=1)$, Hungarian $(\mathrm{n}=1)$, Finnish $(\mathrm{n}=1)$, German $(\mathrm{n}=2)$, Italian $(\mathrm{n}=1)$, and Chinese $(\mathrm{n}=1)$ were excluded due to language restrictions. Among these, 4 would have been selected based on abstract review. For these, 2 full texts were in German (Tenhagen et al., 1999; Zoche-Golob and Spilke, 2013), 1 was in Persian (Mahzoniae et al., 2006), and 1 was in Italian (Colombo et al., 2010). These 4 possibly relevant manuscripts were therefore excluded from the current study.

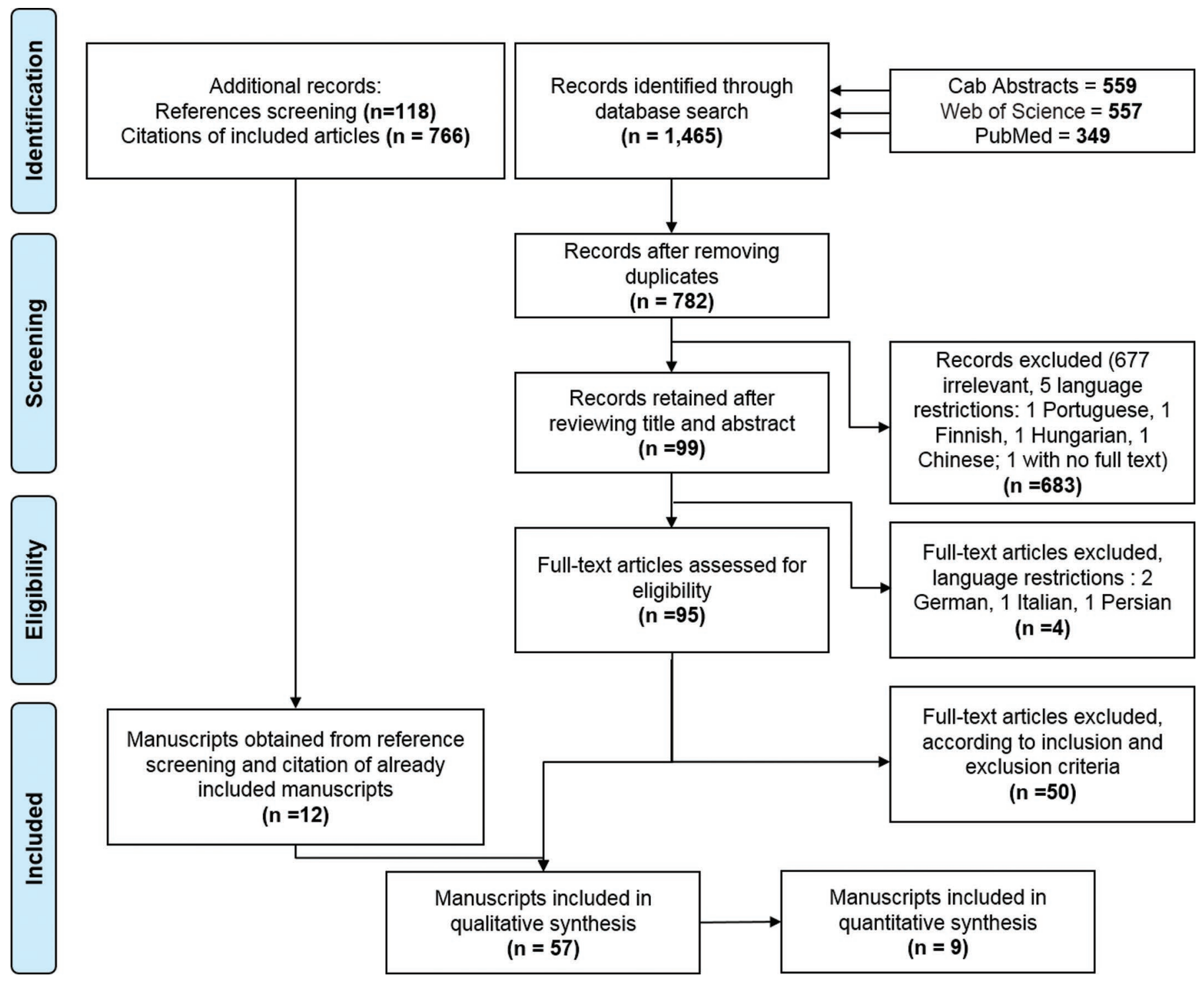

Figure 1. Flow of information through the different phases of the review. Color version available online. 


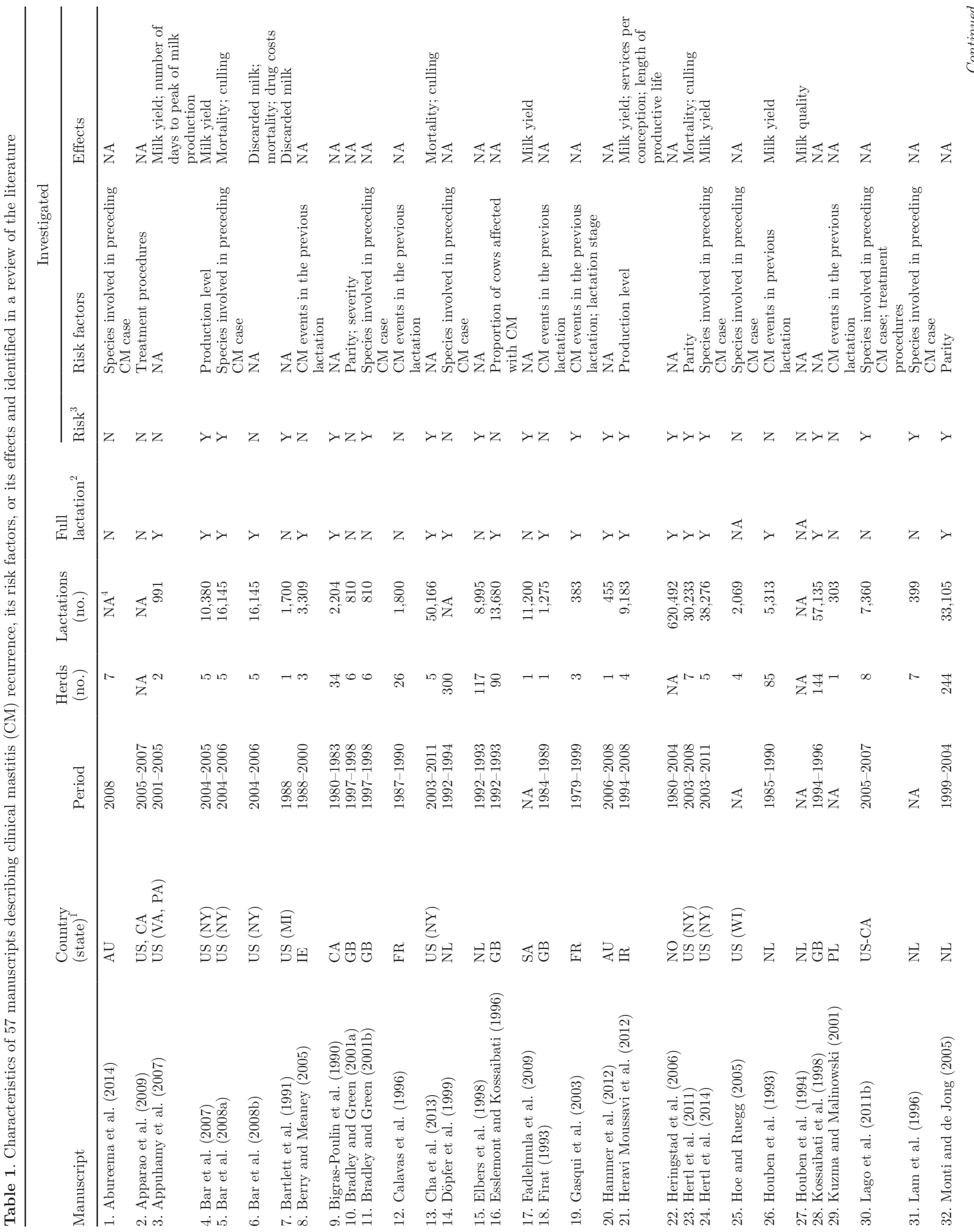


INVITED REVIEW: CLINICAL MASTITIS RECURRENCE

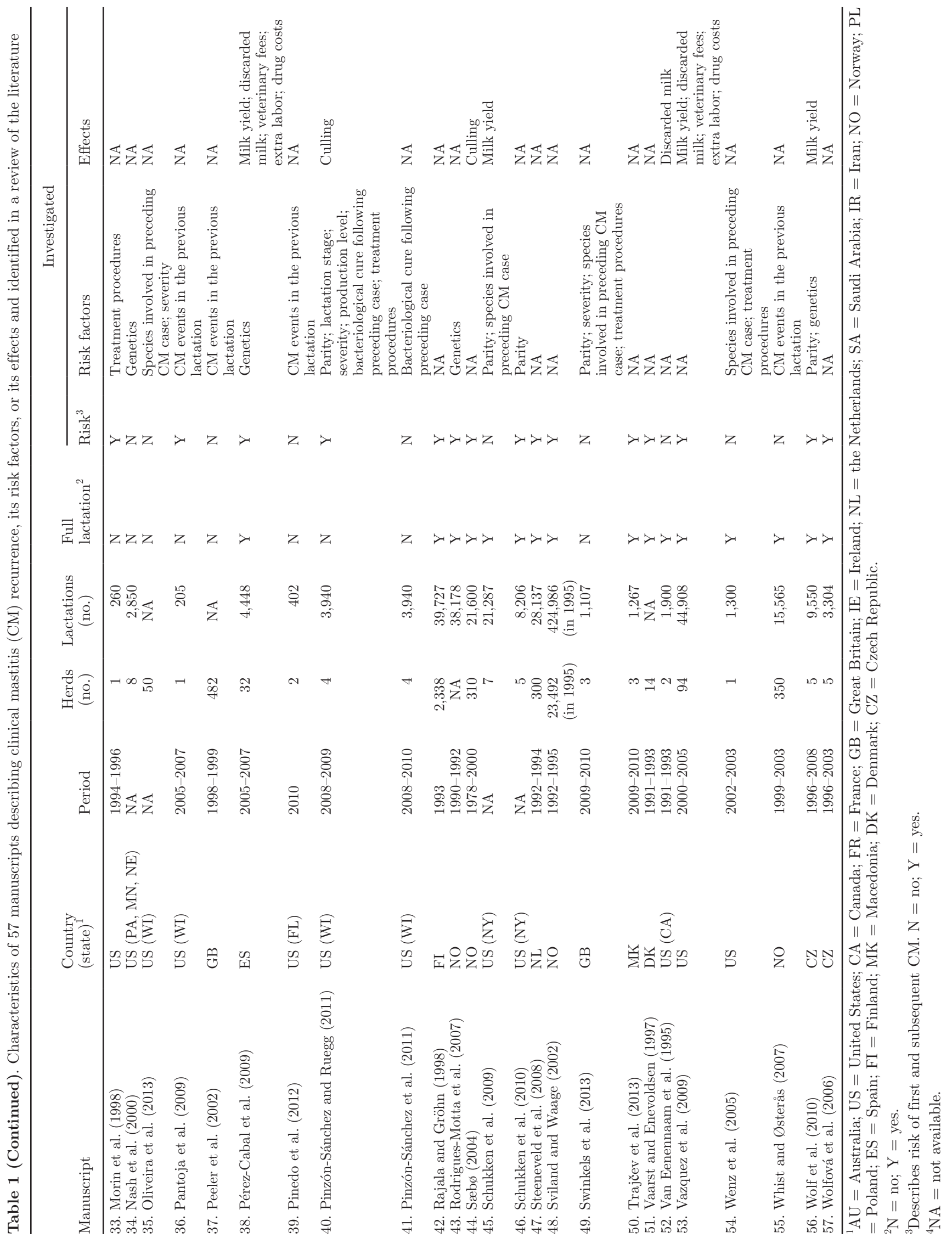




\section{Systematic Review and Meta-Analysis on Risk of CM Recurrence}

Meta-Analysis Results. Definition of CM recurrence used in each study is presented in Table 2 . Among the 57 manuscripts selected in this review, 9 manuscripts presented sufficient data (i.e., number of lactations followed, number of lactations with $\geq 1$ $\mathrm{CM}$ event, number of lactations with $\geq 2 \mathrm{CM}$ events, minimal lag time between $\mathrm{CM}$ events considered in $\mathrm{CM}$ definition, and data source used) to be included in the meta-analysis (Tables 2 and 3). In 4 studies (Rajala and Gröhn, 1998; Sviland and Waage, 2002; Monti and de Jong, 2005; Pérez-Cabal et al., 2009), CM data were obtained from existing databases; all other studies used prospective CM data collection. Regarding the minimal lag time between CM episodes to consider them as independent episodes, 3 studies (Gasqui et al., 2003; Pérez-Cabal et al., 2009; Heravi Moussavi et al., 2012) used a minimum of only $1 \mathrm{~d}$ between $\mathrm{CM}$ episodes in their case definition. Minimal number of days between $\mathrm{CM}$ events used in the other studies ranged from $5 \mathrm{~d}$ (Wolf et al., 2010) to $21 \mathrm{~d}$ (Rajala and Gröhn, 1998). Aside from minimal number of days between CM cases, in most studies the description of the $\mathrm{CM}$ definition used was relatively limited. Most often, CM was simply defined as abnormal milk with or without local signs of inflammation or systemic signs. Whether abnormal milk had to be observed beyond the first stripes of milk was never mentioned. Moreover, observation of CM was conducted by farm personnel in some studies and by research personnel in others. Finally, in some studies, CM recurrence was defined as reoccurrence of $\mathrm{CM}$ in the same quarter, whereas in others it was defined as reoccurrence of CM in the same cow but possibly a different quarter (Table 2). The number of CM events reported in each study is therefore likely to be influenced by all these study features.

Number of lactations followed, number of lactations with $\geq 1$ and $\geq 2 \mathrm{CM}$ cases, CM risks, and RR point estimates are presented for each study in Table 3 . When all studies were considered together, a summary RR of 1.14 (95\% CI: 0.99-1.30) was obtained, indicating a nonsignificant increased susceptibility to $\mathrm{CM}$ after having experienced a first case during the lactation. An $\mathrm{I}^{2}$ statistic of $97 \%$ was obtained, however, indicating considerable heterogeneity between studies.

Results from the univariate meta-regression indicated that differences in source of $\mathrm{CM}$ data used (i.e., data collected specifically for the study vs. use of an existing database) explained only $2.5 \%$ of the between-studies $\mathrm{RR}$ variance. When using an existing database the $\mathrm{RR}$

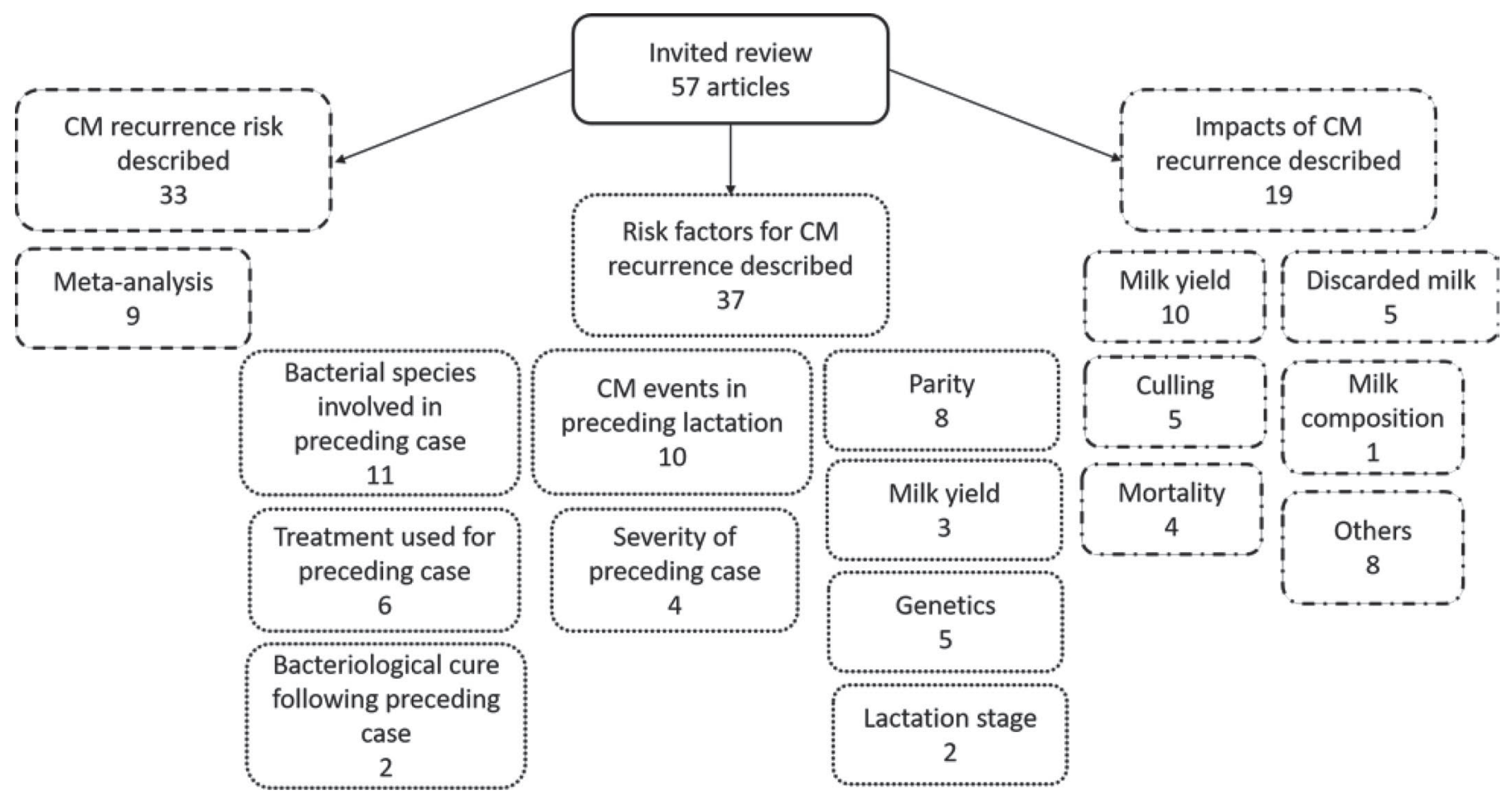

Figure 2. Map of outcomes measured by number of studies in the review. Dashed boxes = number of articles that described risk of clinical mastitis $(\mathrm{CM})$ recurrence; dotted boxes $=$ number of articles that investigated risk factors for CM recurrence; dashed-dotted boxes $=$ number of articles that investigated CM recurrence effects. 
Table 2. Definition of clinical mastitis (CM) recurrence used in 57 manuscripts describing CM recurrence, its risk factors, or its effects and identified in a review of the literature

\begin{tabular}{|c|c|c|}
\hline \multirow[b]{2}{*}{ Manuscript } & \multicolumn{2}{|c|}{$\mathrm{CM}$ recurrence definition } \\
\hline & $\begin{array}{l}\text { Minimum no. of } \\
\text { days between cases }\end{array}$ & $\begin{array}{l}\text { Same quarter }(\mathrm{Q}) \\
\text { vs. same cow (C) }\end{array}$ \\
\hline 1. Abureema et al. (2014) & 10 & $\mathrm{C}$ \\
\hline 2. Apparao et al. (2009) & 8 & $\mathrm{Q}$ \\
\hline 3. Appuhamy et al. (2007) & $\mathrm{NA}^{1}$ & $\mathrm{Q}$ \\
\hline 4. Bar et al. (2007) & 14 & $\mathrm{Q}$ \\
\hline 5. Bar et al. (2008a) & 14 & $\mathrm{Q}$ \\
\hline 6. Bar et al. (2008b) & 14 & $\mathrm{Q}$ \\
\hline 7. Bartlett et al. (1991) & 17 & $\mathrm{C}$ \\
\hline 8. Berry and Meaney (2005) & NA & NA \\
\hline 9. Bigras-Poulin et al. (1990) & 10 & $\mathrm{C}$ \\
\hline 10. Bradley and Green (2001a) & 5 & $\mathrm{Q}$ \\
\hline 11. Bradley and Green (2001b) & 5 & $\mathrm{Q}$ \\
\hline 12. Calavas et al. (1996) & NA & NA \\
\hline 13. Cha et al. (2013) & 14 & $\mathrm{Q}$ \\
\hline 14. Döpfer et al. (1999) & 4 & $\mathrm{C}$ \\
\hline 15. Elbers et al. (1998) & 14 & $\mathrm{Q}$ \\
\hline 16. Esslemont and Kossaibati (1996) & NA & NA \\
\hline 17. Fadlelmula et al. (2009) & NA & NA \\
\hline 18. Firat (1993) & NA & NA \\
\hline 19. Gasqui et al. (2003) & 1 & $\mathrm{Q}$ \\
\hline 20. Hammer et al. (2012) & 30 & $\mathrm{Q}$ \\
\hline 21. Heringstad et al. (2006) & 5 & $\mathrm{C}$ \\
\hline 22. Hertl et al. (2011) & 14 & $\mathrm{C}$ \\
\hline 23. Hertl et al. (2014) & 14 & $\mathrm{C}$ \\
\hline 24. Hoe and Ruegg (2005) & 30 & $\mathrm{Q}$ \\
\hline 25. Houben et al. (1993) & NA & NA \\
\hline 26. Houben et al. (1994) & NA & NA \\
\hline 27. Kossaibati et al. (1998) & 7 & $\mathrm{Q}$ \\
\hline 28. Kuzma and Malinowski (2001) & NA & NA \\
\hline 29. Lago et al. (2011b) & 14 & $\mathrm{Q}$ \\
\hline 30. Lam et al. (1996) & NA & $\mathrm{Q}$ \\
\hline 31. Monti and de Jong (2005) & 8 & $\mathrm{Q}$ \\
\hline 32. Morin et al. (1998) & 14 & $\mathrm{C}$ \\
\hline 33. Heravi Moussavi et al. (2012) & 1 & NA \\
\hline 34. Nash et al. (2000) & 30 & $\mathrm{Q}$ \\
\hline 35. Oliveira et al. (2013) & 14 & $\mathrm{C}$ \\
\hline 36. Pantoja et al. (2009) & NA & NA \\
\hline 37. Peeler et al. (2002) & 8 & $\mathrm{Q} / \mathrm{C}$ \\
\hline 38. Pérez-Cabal et al. (2009) & 1 & NA \\
\hline 39. Pinedo et al. (2012) & NA & NA \\
\hline 40. Pinzón-Sánchez and Ruegg (2011) & NA & $\mathrm{C}$ \\
\hline 41. Pinzón-Sánchez et al. (2011) & NA & $\mathrm{C}$ \\
\hline 42. Rajala and Gröhn (1998) & 21 & NA \\
\hline 43. Rodrigues-Motta et al. (2007) & 5 & $\mathrm{NA}$ \\
\hline 44. $\mathrm{Sæb} \varnothing(2004)$ & NA & NA \\
\hline 45. Schukken et al. (2009) & 14 & $\mathrm{Q}$ \\
\hline 46. Schukken et al. (2010) & 14 & $\mathrm{Q}$ \\
\hline 47. Steeneveld et al. (2008) & 14 & $\mathrm{Q}$ \\
\hline 48. Sviland and Waage (2002) & NA & NA \\
\hline 49. Swinkels et al. (2013) & NA & NA \\
\hline 50. Trajčev et al. (2013) & 9 & NA \\
\hline 51. Vaarst and Enevoldsen (1997) & 30 & $\mathrm{Q}$ \\
\hline 52. Van Eenennaam et al. (1995) & 21 & $\mathrm{Q}$ \\
\hline 53. Vazquez et al. (2009) & NA & NA \\
\hline 54. Wenz et al. (2005) & 15 & $\mathrm{Q}$ \\
\hline 55. Whist and Østerås (2007) & NA & NA \\
\hline 56. Wolf et al. (2010) & 5 & $\mathrm{C}$ \\
\hline 57. Wolfová et al. (2006) & 5 & NA \\
\hline
\end{tabular}

${ }^{1}$ Exact clinical mastitis definition not available. 
Table 3. Results from a meta-analysis conducted using 9 manuscripts identified using a systematic review of the literature and comparing risk of clinical mastitis (CM) in healthy cows with that in cows that already experienced CM in the current lactation ${ }^{1}$

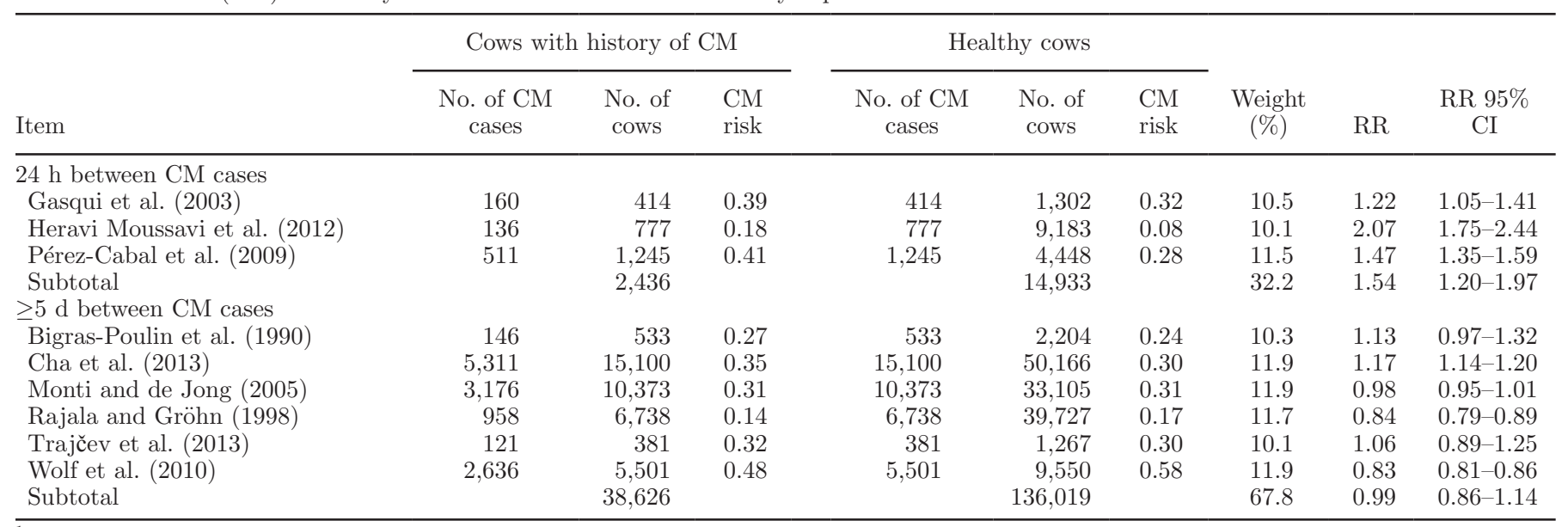

${ }^{1}$ Summary risk ratio (RR) estimates were obtained using a random meta-regression with an inverse variance weighting scheme. Summary measures are presented independently for studies using CM definition requiring only $24 \mathrm{~h}$ between CM cases $(\mathrm{n}=3)$ and for studies requiring at least $5 \mathrm{~d}$ between $\mathrm{CM}$ cases $(\mathrm{n}=6)$.

was multiplied by 0.95 , indicating a numerically—but not statistically - significant lower RR in studies using such a data collection process. Vaarst et al. (2002) reported before that existing national databases are often incomplete with regards to number of CM cases. For instance, cows experiencing multiple CM cases in a given lactation will sometimes have only the first case recorded in such databases because dairy producers do not readily see the benefit of further reporting subsequent cases. We could hypothesize the same to be true with the dairy herd management databases commonly used by dairy producers. Conversely, we could hypothesize that prospective studies explicitly investigating $\mathrm{CM}$ are more likely to yield a more complete recording of CM cases. The lower RR observed in the current review in studies using existing databases as a source of data could, therefore, result from a bias associated with this study design. The fact that this study characteristic explained only $2.5 \%$ of the between-studies variance, however, indicates that the effect of this later bias is possibly negligible.

When regressing the summary effect on the minimum number of days between $2 \mathrm{CM}$ episodes used for case definition (categorized as studies requiring only 24 $\mathrm{h}$ between $\mathrm{CM}$ cases vs. studies requiring at least $5 \mathrm{~d}$ between CM episodes), a substantial proportion (62\%) of the between-studies $\mathrm{RR}$ variance could be explained. When using a CM case definition requiring at least $5 \mathrm{~d}$ between $\mathrm{CM}$ cases, $\mathrm{RR}$ was multiplied by 0.84 , indicating lower RR in studies using such a case definition, as would be expected. Risk ratios ranging between 1.22 and 2.07 were reported in the 3 studies using a CM definition requiring only $24 \mathrm{~h}$ between cases (Table 3 and Figure 3). Risk ratios ranging between 0.83 and
1.17 were reported in the 6 studies with $\mathrm{CM}$ definition requiring $\geq 5 \mathrm{~d}$ between $\mathrm{CM}$ cases. In this later subgroup, 2 studies observed a decreased CM risk following a first $\mathrm{CM}$ event, 3 observed a maintained risk, and 1 observed an increased risk (Table 3; Figure 3). Although a substantial number of studies have investigated CM, there is currently no consensus on the minimal number of days between $2 \mathrm{CM}$ episodes that should be used to define an incident CM case. In 1997, the international dairy federation proposed a lag time of $8 \mathrm{~d}$, without any biological explanations, for differentiating a continuing CM case from a new episode (International Dairy Federation, 1997). In the current review, various lag time categorizations were evaluated in the univariate meta-regression. When categorizing studies by minimum lag time using thresholds of $8,9,10,14$, or 21 $\mathrm{d}$, between-studies variance explained always remained $<10 \%$, indicating that the main heterogeneity between studies resided from comparing studies considering only $24 \mathrm{~h}$ between $2 \mathrm{CM}$ cases with studies requiring at least $5 \mathrm{~d}$ between episodes. Above a threshold of $5 \mathrm{~d}$ between $2 \mathrm{CM}$ cases, the exact threshold used appears to have little effect on RR estimation.

To account for the important heterogeneity due to CM case definition, separate summary effects were computed for studies considering only $24 \mathrm{~h}$ between $2 \mathrm{CM}$ cases and for studies considering at least $5 \mathrm{~d}$ between CM cases (Table 3; Figure 3). For studies considering only a 24-h lag time between $2 \mathrm{CM}$ events, cows that already experienced a CM case in the current lactation had a 1.54 times higher CM risk than healthy cows (95\% CI: 1.20-1.97). For studies requiring $\geq 5 \mathrm{~d}$ between $\mathrm{CM}$ events to consider a $\mathrm{CM}$ event as a new case, a similar maintained CM risk was observed 


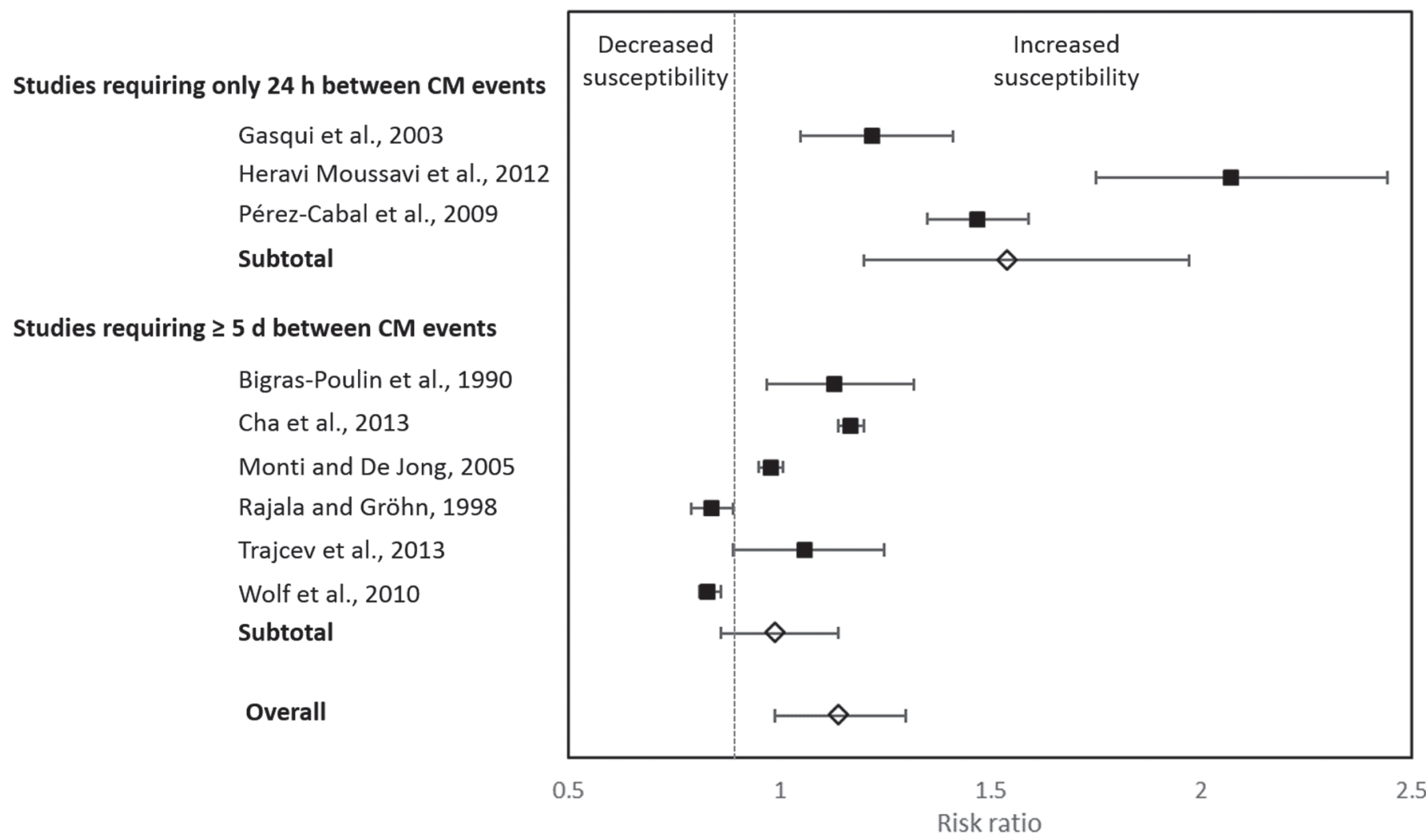

Figure 3. Forest plot of risk of clinical mastitis $(\mathrm{CM})$ event among cows having already experienced a CM event in the current lactation compared with risk in healthy cows. Summary effects presented as a function of CM case definition used (only $24 \mathrm{~h}$ between CM cases vs. $\geq 5 \mathrm{~d}$ between cases). Filled squares indicate the risk ratio point estimate for a given study, whereas open diamonds represent the summary estimate for a subgroup of studies. Error bars represent the $95 \%$ CI.

after the first CM case (RR: 0.99; 95\% CI: 0.86-1.14). Although a consensual definition of CM is not currently available, we would suggest interpreting the summary effect for studies considering only $24 \mathrm{~h}$ between cases with great caution. A substantial proportion of the apparently new cases occurring in a same quarter within $24 \mathrm{~h}$ of a previous CM case should possibly be considered a continuation of the initial case. Including these 3 studies that used only a minimum of $1 \mathrm{~d}$ between CM events to compute an overall summary effect, however, had little effect on conclusions regarding change in CM risk following a first CM case. Apparently this risk is neither reduced nor increased after a first case; it is simply maintained (i.e., RR close to 1.0 and $95 \%$ CI including the null value). This summary measure, however, was computed using a limited number of studies conducted in specific geographical regions (Canada, United States, the Netherlands, Finland, Macedonia, and the Czech Republic) and time periods (1980-2011; Table 1). This summary measure may not apply to cows from other countries or to different time periods.

At first glance, our meta-analysis results seem to suggest that cows do not develop short-term im- munity against CM. We could hypothesize, however, that some cows are intrinsically more susceptible to CM than others (because of genetics, milk production, conformation, and so on). Then, we would expect these susceptible cows to be overrepresented compared with the general population of cows in the denominator in Equation 2. The greater proportion of susceptible cows in the population used to estimate $\mathrm{R}_{\mathrm{CM}}$ in Equation 2 should then, theoretically, yield an $\mathrm{RR}>1.0$. Observing an $\mathrm{RR}$ close to 1.0 could, therefore, be the result of a competition between (1) following a population of cows that is intrinsically more susceptible to CM and (2) establishment of a certain level of immunity toward CM that would better protect these susceptible cows against subsequent $\mathrm{CM}$ cases. The maintained risk of $\mathrm{CM}$ following a first CM case is likely the result of the interplay between development of immunity and shift in a population's susceptibility.

Finally, few differences were observed when excluding studies one at a time to evaluate their influence on the overall or subgroup summary measures of effect. Regarding the overall summary effect, removing a given study yielded an RR between 1.06 and 1.19. 
Removing either the Rajala and Gröhn (1998) or the Wolf et al. (2010) studies, however, yielded a 95\% CI not including the null value. Regarding the subgroup summary effect, removing studies one at a time yielded an $\mathrm{RR}$ ranging between 1.35 and 1.73 and between 0.94 and 1.02 for the 24-h only and $\geq 5 \mathrm{~d}$ between CM subgroups, respectively. When removing the Pérez-Cabal et al. (2009) study from the 24-h only summary effect between CM subgroups, a maintained similar CM risk following a first CM case value was then observed for that subgroup.

The funnel plot sketched for investigating publication bias is presented as Supplemental Figure S1 (https:// doi.org/10.3168/jds.2017-13730). With the limited number of studies per subgroup, the presence of a publication bias could not be ruled out. However, there was no apparent evidence of publication bias (i.e., the funnel plot was relatively symmetrical, even in areas representing studies with large standard errors). Results from the risk of bias evaluation are presented as Supplemental Table S1 (https://doi.org/10.3168/jds .2017-13730). The main issue observed was the fact that the outcome, CM, was self-reported by producers in most studies except the Gasqui et al. (2003) study, where it was recorded by research personnel. In that latter study, however, the exposed cohorts were recruited within 3 research herds, which may not be representative of the population.

Other Reports. Beyond the data that could be compiled in the meta-analysis, many of the selected manuscripts also described risk of $\mathrm{CM}$ recurrence in various manners. Schukken et al. (2010) and Hertl et al. (2014) reported that the hazard of a cow to have $\mathrm{CM}$ increased with $\mathrm{CM}$ event number. Others reported that cows that experienced CM recently were 2.8 times more likely to have a CM event compared with CM-free cows (Berry and Meaney, 2005; Steeneveld et al., 2008). Hammer et al. (2012), however, did not observe an increased risk of $\mathrm{CM}$ for cows that already experienced a CM during the first 30 DIM or between 30 and 90 DIM. Finally, Vaarst and Enevoldsen (1997) did not report whether risk increases following an initial CM event, but they did report a cumulative CM recurrence risk of 0.32 (95\% CI: $0.27-0.37)$ in their study. This CM recurrence risk would be considered relatively high compared with those of studies included in the metaanalysis of the current review (see the CM risk column for cows with history of CM in Table 3).

\section{Narrative Review on Effect of CM Recurrence}

Discarded Milk. The effect of repeated CM cases on discarded milk was investigated in a few of the selected studies (Bartlett et al., 1991; Van Eenennaam et al., 1995; Bar et al., 2008b; Pérez-Cabal et al., 2009; Vazquez et al., 2009). Estimates of discarded milk in the $60 \mathrm{~d}$ following the first $\mathrm{CM}$ or a subsequent $\mathrm{CM}$ case of 266 and of $220 \mathrm{~kg}$, respectively, were reported by Bartlett et al. (1991). In another study, discarded milk economic losses in a given lactation were US $\$ 116$, $\$ 109$, and $\$ 112$ following the first, second, and third CM episodes, respectively (Pérez-Cabal et al., 2009). In both studies, amount of discarded milk was therefore relatively similar following first and recurrent CM events. These results suggest that recurrent CM events are possibly of similar duration as the initial CM event or are treated in a similar way by dairy producers, thus leading to the same amount of milk discarded.

Mortality. The effect of recurrent cases of CM on mortality risk was investigated in numerous studies (Bar et al., 2008a,b; Hertl et al., 2011; Cha et al., 2013). In general, occurrence of a first or recurrent CM case led to higher mortality risk (Cha et al., 2013). Moreover, some reported that the mortality risk in the month when CM was diagnosed was 6,23 , and 28 times greater than that in healthy cows following the first, second, and third CM events, respectively (Bar et al., 2008a). Thus, recurrent CM cases apparently take a toll on the cow's ability to survive. Similarly, Hertl et al. (2011) and Cha et al. (2013) reported an increased mortality risk in cows suffering from a second CM case caused by gram-negative pathogens. However, CM caused by some pathogens such as Streptococcus spp. (a gram-positive bacteria) had a protective effect on the subsequent mortality risk (Cha et al., 2013).

Milk Yield. Milk yield reduction following CM is one of the main economic loss components. Milk yield reduction following CM is influenced by the cow's age, breed, udder morphology, milk production before a CM event, whether preceding CM were observed during the same or previous lactation, degree of inflammation, pathogen involved, CM duration, treatment, feeding, and season (Petrovski et al., 2006). We can clearly conclude from the reviewed articles that recurrent CM in the same or previous lactation has an effect on milk yield and milk production persistency (Houben et al., 1993; Wilson et al., 2004; Appuhamy et al., 2007; Bar et al., 2007; Fadlelmula et al., 2009; Pérez-Cabal et al., 2009; Schukken et al., 2009; Vazquez et al., 2009; Wolf et al., 2010; Heravi Moussavi et al., 2012; Hertl et al., 2014). More specifically, Bar et al. (2007) reported in multiparous cows milk yield reduction of 141 and 119 $\mathrm{kg}$ in the first 2 mo after the second and third CM episodes, respectively. Furthermore, another study reported that primiparous cows with recurrent CM produced $12.5 \%$ less milk than those with only $1 \mathrm{CM}$ case (Heravi Moussavi et al., 2012). Others reported milk yield reduction following the first, second, and third 
cases varying from 47 to $166 \mathrm{~kg}, 54$ to $96 \mathrm{~kg}$, and 11 to $324 \mathrm{~kg}$, respectively (Houben et al., 1994; Pérez-Cabal et al., 2009).

In the study by Schukken et al. (2009), milk yield reduction varied as a function of the causal organism irrespective of number of CM episodes. For instance, gram-negative infections caused greater milk yield reduction than infections caused by other organisms. Although the highest milk yield reduction was observed in the first case of gram-negative $\mathrm{CM}$ infections, in gram-positive CM cases the larger milk yield reductions were those of the third case (Schukken et al., 2009). Cows affected with clinical mastitis had milk yield reduction of 93 to $193 \mathrm{~kg}$ for recurrent gram-positive CM (compared with $128 \mathrm{~kg}$ for a first case) and 276 to 295 $\mathrm{kg}$ for recurrent gram-negative CM (compared with 304 $\mathrm{kg}$ following a first gram-negative CM case; Schukken et al., 2009).

In most instances, milk yield reduction was estimated by comparing milk production of cows affected with recurrent $\mathrm{CM}$ events with that of cows not affected by recurrent events. It should be noted, though, that highproducing cows are more at risk of CM and of recurrent $\mathrm{CM}$ events. Therefore, comparing the production level of a cow with $\mathrm{CM}$ or recurrent $\mathrm{CM}$ with that of healthy herd mates may not fully capture the milk yield reduction following these CM events. For a more accurate assessment, the milk production of a CM-diseased cow should be compared with her estimated potential based on her milk production before the CM event. Nevertheless, it is clear that milk yield reduction following recurrent CM events leads to substantial milk yield reduction and that this reduction is possibly comparable with that of first CM cases.

Culling. Culling losses due to first and subsequent CM cases have a substantial effect on dairy farms' profitability. Having 1 or multiple CM tends to increase the risk of culling (Heravi Moussavi et al., 2012). However, producers consider many cow-related factors such as age, milk yield, stage of lactation, reproductive performance, and health status to determine whether a cow should be culled (Petrovski et al., 2006).

Results from the selected studies showed that the risk of culling increased with the number of $\mathrm{CM}$ cases (Sæbø, 2004; Pinzón-Sánchez and Ruegg, 2011). A higher proportion of cows that experienced only $1 \mathrm{CM}$ case $(92 \%)$ remained in the herd compared with those with recurrent CM cases (76\%) during a same lactation (Pinzón-Sánchez and Ruegg, 2011). The odds of culling a cow after a third CM event were 4 times higher than those of a CM-free cow (Bar et al., 2008a). In a study in the northeast United States, the researchers initially observed that all CM cases during lactation increased the culling risk regardless of the number of cases and pathogen type (Hertl et al., 2011). Later on, this group of researchers was able to underline that the type of pathogen that caused the CM also influences the culling risk. For example, Cha et al. (2013) reported that the culling risk in primiparous and multiparous cows increased after multiple cases of Klebsiella CM. Results from the current review strongly support, as expected, that CM recurrence does increase culling risk.

Milk Quality. Although milk quality reduction is an important factor when calculating the economic effect of CM, only 1 manuscript investigated the changes in milk quality following recurrent CM events. The synthesis of the main milk components (protein, fat, and lactose) diminishes following a CM event. Furthermore, due to inflammatory reaction, the concentration of blood serum components increases (Beck et al., 1992; DeGraves and Fetrow, 1993; Hortet and Seegers, 1998). These changes can lead to inferior milk quality (Trajkovski et al., 1997) and milk yield (Allore and Erb, 1998).

Although the effect of a first or subsequent CM event on fat yield was most often not significant during the month of the event, experiencing multiple CM cases in a given lactation has a long-term cumulative effect on fat yield in that lactation. Houben et al. (1994) reported that in multiparous cows with $\mathrm{CM}$, lactational fat and protein yields were respectively decreased by 6.9 and $4.5 \mathrm{~kg}$ after the first CM case, by 12 and 1.5 $\mathrm{kg}$ after the second, and by 7.9 and $11 \mathrm{~kg}$ after the third or subsequent CM cases. In many countries, the milk payment system is based on protein and fat yield; therefore, reduced quantities of protein or fat can be directly translated in economic losses for dairy producers. With results from a single study being available, however, we can hardly draw conclusions on the effect of recurrent CM cases on milk composition.

Other Effects of CM Recurrence. Other CM recurrence effects observed in a few of the manuscripts selected for this study included increased veterinary fees (Pérez-Cabal et al., 2009; Vazquez et al., 2009), increased use of drugs (Bar et al., 2008b; Pérez-Cabal et al., 2009; Vazquez et al., 2009), extra labor (Pérez-Cabal et al., 2009; Vazquez et al., 2009), increased number of services per conception, lower length of productive life (Heravi Moussavi et al., 2012), and decreased number of days to peak milk production (Appuhamy et al., 2007).

\section{Narrative Review of CM Recurrence Risk Factors}

Parity. Parity has a clear effect on the number of $\mathrm{CM}$ events and on $\mathrm{CM}$ recurrence risk, with higher parity cows having an increased risk of experiencing repeated CM cases (Monti and de Jong, 2005; Wolf 
et al., 2010; Swinkels et al., 2013). More specifically, Pinzón-Sánchez and Ruegg (2011) reported that a cow with $\geq 3$ lactations was 15 times more likely to experience recurrent $\mathrm{CM}$ events compared with a primiparous cow. Similarly, Hertl et al. (2011) observed that a larger proportion of multiparous cows, compared with primiparous cows, experienced second (11 vs. 3.7\%) or third (4.4 vs. $1.1 \%$ ) CM events. In the study by Wolf et al. (2010), 19, 27, 36, and 39\% of first-, second-, third-, and $\geq$ fourth-parity cows, respectively, experienced $\geq 2$ $\mathrm{CM}$ cases in a given lactation.

Parity was found to be a risk factor for new IMI in general, suggesting that the cow's intramammary and anatomical (e.g., teat sphincter patency) defense mechanisms may deteriorate with age (Zadoks et al., 2001; Green et al., 2002; Dingwell et al., 2004). These substandard defense mechanisms may explain the higher incidence of $\mathrm{CM}$ and recurrent $\mathrm{CM}$ in older cows. Results from the current review support the positive relationship between parity and risk of CM recurrence.

Lactation Stage. Although lactation stage was not significantly associated with days until the next CM event in one study (Gasqui et al., 2003), Pinzón-Sánchez and Ruegg (2011) reported that cows that experienced recurrent $\mathrm{CM}$ within $60 \mathrm{~d}$ of the preceding event had a first $\mathrm{CM}$ event earlier in their lactation compared with those that did not experience recurrent CM. Changes in immune functions as well as nonspecific host defense mechanisms may be a cause of the high incidence rate of CM in early lactation. Results from our review, however, could not confirm whether CM recurrence risk increases when the first CM occurred early during the lactation. More research would be needed to confirm the observation made by Pinzón-Sánchez and Ruegg (2011).

Genetics. Using the best over the worst sire regarding CM and SCS could decrease the number of CM events per lactation in daughters (Rodrigues-Motta et al., 2007; Pérez-Cabal et al., 2009; Wolf et al., 2010). Nash et al. (2000) reported estimates of heritability for the total number of $\mathrm{CM}$ cases during first and second lactation of 42 and 15\%, respectively. Selection for longer productive life, stronger udder attachment, shallower udders, or deeper udder cleft may also reduce the number of CM events per lactation (Nash et al., 2000).

Production Level. High milk production was observed by many as a risk factor in the development of CM and recurrent CM cases (Lescourret et al., 1995; Allore and Erb, 1998; Bar et al., 2007; Heravi Moussavi et al., 2012). A positive relationship between milk production potential and number of CM episodes was also reported by Lescourret et al. (1995). However, milk production before the initial case was not associated with CM recurrence risk in one study (Pinzón-Sánchez and Ruegg, 2011). Results from the scientific literature rather suggest that high-producing dairy cattle are more inclined to have CM recurrence.

Severity of Preceding CM Case. In numerous studies, CM recurrence was not associated with the severity of the initial CM case (Pinzón-Sánchez and Ruegg, 2011; Oliveira et al., 2013; Swinkels et al., 2013). Bradley and Green (2001a), however, reported that first E. coli CM cases were less likely to be mild compared with recurrent CM cases. Despite this later finding, we can possibly safely conclude that the severity of the preceding case is not associated with subsequent CM recurrence risk.

Species Involved in a Preceding CM Case. Pathogen species involved in preceding CM was identified as a risk factor for $\mathrm{CM}$ recurrence in several studies (Bradley and Green, 2001b; Wenz et al., 2005; Schukken et al., 2009; Lago et al., 2011b; Oliveira et al., 2013; Swinkels et al., 2013; Abureema et al., 2014; Hertl et al., 2014). Bar et al. (2008a) and Bradley and Green (2001b) found that about half of repeated CM cases were caused by the same pathogen species identified in the preceding case. In one study, the CM recurrence cumulative incidence within the 90-d follow-up period was higher in cows that experienced gram-negative CM (31\%) compared with gram-positive CM (21\%; Oliveira et al., 2013). However, Hoe and Ruegg (2005) reported that recurrent $\mathrm{CM}$ rate $30 \mathrm{~d}$ after the initial CM case was not different between CM cases caused by grampositive and gram-negative pathogens. Wenz et al. (2005) found that CM-diseased cows with mixed (both gram-negative and gram-positive) infections were 8.9 times more likely to have CM recurrence from 15 to 90 d after the initial CM case than cows suffering from a gram-positive infection. Lam et al. (1996) and Swinkels et al. (2013) reported that Staphylococcus aureus and Streptococcus uberis recurrent CM events were observed more frequently than E. coli recurrent CM events. However, Döpfer et al. (1999) documented that the same E. coli genotype was identified in $86 \%$ of $E$. coli $\mathrm{CM}$ recurrence cases.

With the current review, we can conclude that the pathogen initially involved in the first CM case is an important determinant of the subsequent $\mathrm{CM}$ recurrence risk. It is not clear, however, which pathogen species or group is more likely to lead to recurrent events. The persistence of the IMI following the initial CM case is possibly an important causal component for subsequent $\mathrm{CM}$ recurrence.

Bacteriological Cure Following a Preceding Case. The estimated probability of CM recurrence in primiparous cows was, respectively, 2 and $25 \%$ for $\mathrm{CM}$ cases that resulted in bacteriological cure or not (Pinzón-Sánchez et al., 2011). Similarly, for multiparous 
cows, the estimated $\mathrm{CM}$ recurrence probability was, respectively, 12 and $35 \%$ for $\mathrm{CM}$ cases that resulted in bacteriological cure or not (Pinzón-Sánchez et al., 2011). Cows with bacteriological cure were, therefore, 8 times less likely to have a CM recurrence than those that did not experience a bacteriological cure (PinzónSánchez and Ruegg, 2011). These results, however, could not be confirmed by any of the other selected articles.

Treatment. In one study, the proportion of antimicrobial-treated cows that had a subsequent CM case involving the originally affected quarter during the CM period (60 d after the initial CM case) was significantly lower than that of cows receiving only supportive treatment (29 vs. 46\%; Morin et al., 1998). On the other hand, Lago et al. (2011b) reported that there were no differences in the risk of $\mathrm{CM}$ recurrence or in time to $\mathrm{CM}$ recurrence between cows immediately treated with a cephapirin sodium intramammary treatment at CM diagnosis and cows submitted to an on-farm culturebased treatment strategy in which treatment is usually delayed by $24 \mathrm{~h}$. Moreover, in another study the treatment strategy (treatment with different antimicrobials) used was not significantly associated with $\mathrm{CM}$ recurrence risk between 15 and $90 \mathrm{~d}$ after the initial $\mathrm{CM}$ case (Wenz et al., 2005). However, a more aggressive and extended treatment was found to be helpful in preventing CM recurrence in one study (Swinkels et al., 2013). Furthermore, a tendency for a lower risk of $\mathrm{CM}$ recurrence (1.3 times lower risk) was reported for every additional day of treatment by Pinzón-Sánchez and Ruegg (2011). Although there are many contradictory results on treatment procedure as a risk factor for CM recurrence, it seems that treatment strategy is an important determinant of $\mathrm{CM}$ recurrence and that extended treatment may be useful for avoiding recurrent episodes of CM.

CM Events in the Previous Lactation. In many studies, the presence of a CM event in the previous lactation was found to be a risk factor for CM recurrence in the subsequent lactation (Firat, 1993; Houben et al., 1993; Calavas et al., 1996; Kuzma and Malinowski, 2001; Peeler et al., 2002; Berry and Meaney, 2005; Whist and Østerås, 2007; Pantoja et al., 2009; Pinedo et al., 2012). Clinical mastitis events in the previous lactation increased the risk of $\mathrm{CM}$ in the subsequent lactation by a factor of 1.5 to 3.8 (Firat, 1993; Houben et al., 1993; Calavas et al., 1996; Gasqui et al., 2003; Berry and Meaney, 2005; Whist and Østerås, 2007; Pinedo et al., 2012). Pantoja et al. (2009) reported that CM events in the last $60 \mathrm{~d}$ of the previous lactation were significantly associated with higher odds of $\mathrm{CM}$ events during the first $60 \mathrm{~d}$ postcalving (odds ratio $=4.1$ ). In another study, the cumulative $\mathrm{CM}$ incidence risk during the current lactation for cows that had CM in the previous lactation was reported to be higher (59\%) compared with cows not experiencing $\mathrm{CM}$ in the previous lactation (37\%) and heifers (36\%; Kuzma and Malinowski, 2001).

\section{CONCLUSIONS}

Results from our meta-analysis suggest that CM risk is not increased or reduced but simply maintained following an initial CM event. Clinical mastitis case definition, however, substantially affected the computed $\mathrm{RR}$ describing $\mathrm{CM}$ recurrence risk. Recurrent CM case definitions varied among studies, especially regarding the minimal time required between $2 \mathrm{CM}$ events, which ranged from $\geq 1 \mathrm{~d}$ to $\geq 30 \mathrm{~d}$. Our results suggest that studies using any threshold $\geq 5 \mathrm{~d}$ between cases would be comparable. In our narrative review, we highlighted the role of parity, pathogen species involved in preceding $\mathrm{CM}$, and lactation stage as important risk factors associated with CM recurrence. Furthermore, we discussed some of the most important effects of recurrent CM: milk yield reduction and increased risk of culling and mortality.

\section{ACKNOWLEDGMENTS}

This research was supported mainly by Agriculture and Agri-Food Canada (Ottawa, ON, Canada) and by additional contributions from Dairy Farmers of Canada (Ottawa, ON, Canada), the Canadian Dairy Network (Guelph, ON, Canada), and the Canadian Dairy Commission (Ottawa, ON, Canada) under the Agri-Science Clusters Initiative. The project was also supported by the Natural Sciences and Engineering Research Council of Canada Discovery Grant to the senior author (S. D.). The first author (H. J.) was supported by a Natural Sciences and Engineering Research Council of Canada-Collaborative Research and Training Experience in milk quality scholarship. Per the research agreement, aside from providing financial support, the funders have no role in the design and conduct of the studies, data collection, and analysis or interpretation of the data. The researchers maintain independence in conducting their studies, own their data, and report the outcomes regardless of the results. The decision to publish the findings rests solely with the researchers.

\section{REFERENCES}

Abureema, S., P. Smooker, J. Malmo, and M. Deighton. 2014. Molecular epidemiology of recurrent clinical mastitis due to Streptococcus uberis: Evidence of both an environmental source and recurring infection with the same strain. J. Dairy Sci. 97:285-290. 
Allore, H. G., and H. N. Erb. 1998. Partial budget of the discounted annual benefit of mastitis control strategies. J. Dairy Sci. 81:22802292.

Apparao, M., P. Ruegg, A. Lago, S. Godden, R. Bey, and K. Leslie. 2009. Relationship between in vitro susceptibility test results and treatment outcomes for gram-positive mastitis pathogens following treatment with cephapirin sodium. J. Dairy Sci. 92:2589-2597.

Appuhamy, J. A. D. R. N., B. G. Cassell, C. D. Dechow, and J. B Cole. 2007. Phenotypic relationships of common health disorders in dairy cows to lactation persistency estimated from daily milk weights. J. Dairy Sci. 90:4424-4434.

Bar, D., Y. T. Gröhn, G. Bennett, R. N. Gonzalez, J. A. Hertl, H. F. Schulte, L. W. Tauer, F. L. Welcome, and Y. H. Schukken. 2007. Effect of repeated episodes of generic clinical mastitis on milk yield in dairy cows. J. Dairy Sci. 90:4643-4653.

Bar, D., Y. T. Gröhn, G. Bennett, R. N. González, J. A. Hertl, H. F. Schulte, L. W. Tauer, F. L. Welcome, and Y. H. Schukken. 2008a. Effects of repeated episodes of generic clinical mastitis on mortality and culling in dairy cows. J. Dairy Sci. 91:2196-2204.

Bar, D., L. W. Tauer, G. Bennett, R. N. Gonzalez, J. A. Hertl, Y. H. Schukken, H. F. Schulte, F. L. Welcome, and Y. T. Gröhn. 2008b. The cost of generic clinical mastitis in dairy cows as estimated by using dynamic programming. J. Dairy Sci. 91:2205-2214.

Barbano, D. M., Y. Ma, and M. V. Santos. 2006. Influence of raw milk quality on fluid milk shelf life. J. Dairy Sci. 89(Suppl. 1):E15-E19.

Barnouin, J., N. Geromegnace, M. Chassagne, N. Dorr, and P. Sabatier. 1999. Facteurs structurels de variation des niveaux de comptage cellulaire du lait et de fréquence des mammites cliniques dans 560 élevages bovins répartis dans 2départements français. INRA Prod. Anim. 12:39-48.

Bartlett, P. C., J. Van Wijk, D. J. Wilson, C. D. Green, G. Y. Miller, G. A. Majewski, and L. E. Heider. 1991. Temporal patterns of lost milk production following clinical mastitis in a large Michigan Holstein herd. J. Dairy Sci. 74:1561-1572.

Beck, H. S., W. S. Wise, and F. H. Dodd. 1992. Cost benefit analysis of bovine mastitis in the UK. J. Dairy Res. 59:449-460.

Berry, D. P., and W. J. Meaney. 2005. Cow factors affecting the risk of clinical mastitis. Ir. J. Agric. Food Res. 44:147-156.

Bigras-Poulin, M., A. H. Meek, S. W. Martin, and I. McMillan. 1990. Health problems in selected Ontario Holstein cows: Frequency of occurrences, time to first diagnosis and associations. Prev. Vet. Med. 10:79-89.

Bradley, A. J., and M. J. Green. 2001a. Adaptation of Escherichia coli to the bovine mammary gland. J. Clin. Microbiol. 39:1845-1849.

Bradley, A. J., and M. J. Green. 2001b. Aetiology of clinical mastitis in six Somerset dairy herds. Vet. Rec. 148:683-686.

Calavas, D., B. Faye, F. Bugnard, C. Ducrot, and F. Raymond. 1996 Analysis of associations among diseases in French dairy cows in two consecutive lactations. Prev. Vet. Med. 27:43-55.

Cha, E., D. Bar, J. A. Hertl, L. W. Tauer, G. Bennett, R. N. González, Y. H. Schukken, F. L. Welcome, and Y. T. Gröhn. 2011. The cost and management of different types of clinical mastitis in dairy cows estimated by dynamic programming. J. Dairy Sci. 94:4476-4487.

Cha, E., J. A. Hertl, Y. H. Schukken, L. W. Tauer, F. L. Welcome, and Y. T. Gröhn. 2013. The effect of repeated episodes of bacteriaspecific clinical mastitis on mortality and culling in Holstein dairy cows. J. Dairy Sci. 96:4993-5007.

Colombo, M., F. Sicilia, and V. Bronzo. 2010. Cost of clinical mastitis in Italian herds. Large Anim. Rev. 16:93-95.

DeGraves, F. J., and J. Fetrow. 1993. Economics of mastitis and mastitis control. Vet. Clin. North Am. Food Anim. Pract. 9:421-434.

Dingwell, R. T., K. E. Leslie, Y. H. Schukken, J. M. Sargeant, L. L. Timms, T. F. Duffield, G. P. Keefe, D. F. Kelton, K. D. Lissemore, and J. Conklin. 2004. Association of cow and quarter-level factors at drying-off with new intramammary infections during the dry period. Prev. Vet. Med. 63:75-89.

Döpfer, D., H. W. Barkema, T. J. G. M. Lam, Y. H. Schukken, and W. Gaastra. 1999. Recurrent clinical mastitis caused by Escherichia coli in dairy cows. J. Dairy Sci. 82:80-85.

Elbers, A. R. W., J. D. Miltenburg, D. De Lange, A. P. P. Crauwels, H. W. Barkema, and Y. H. Schukken. 1998. Risk factors for clinical mastitis in a random sample of dairy herds from the southern part of The Netherlands. J. Dairy Sci. 81:420-426.

Elghafghuf, A., S. Dufour, K. Reyher, I. Dohoo, and H. Stryhn. 2014. Survival analysis of clinical mastitis data using a nested frailty Cox model fit as a mixed-effects Poisson model. Prev. Vet. Med. 117:456-468.

Esslemont, R. J., and M. A. Kossaibati. 1996. Incidence of production diseases and other health problems in a group of dairy herds in England. Vet. Rec. 139:486-490.

Fadlelmula, A., A. M. Al Dughaym, G. E. Mohamed, M. K. Al Deib, and A. J. Al Zubaidy. 2009. Bovine mastitis: Epidemiological, clinical and etiological study in a Saudi Arabian large dairy farm. Bulg. J. Vet. Med. 12:199-206.

Firat, M. Z. 1993. Susceptibility of clinical mastitis in successive lactations. Livest. Prod. Sci. 34:175-180.

Friedman, S., E. Shoshani, and E. Ezra. 2004. Economical losses from clinical mastitis in 4 dairy herds in Israel. Isr. J. Vet. Med. 59:1619.

Gasqui, P., J. B. Coulon, and O. Pons. 2003. An individual modelling tool for within and between lactation consecutive cases of clinical mastitis in the dairy cow: An approach based on a survival model Vet. Res. 34:85-104.

Green, M. J., L. E. Green, G. F. Medley, Y. H. Schukken, and A. J. Bradley. 2002. Influence of dry period bacterial intramammary infection on clinical mastitis in dairy cows. J. Dairy Sci. 85:25892599

Gröhn, Y. T., D. J. Wilson, R. N. González, J. A. Hertl, H. Schulte G. Bennett, and Y. H. Schukken. 2004. Effect of pathogen-specific clinical mastitis on milk yield in dairy cows. J. Dairy Sci $87: 3358-3374$

Halasa, T., K. Huijps, O. Østerås, and H. Hogeveen. 2007. Economic effects of bovine mastitis and mastitis management: A review. Vet. Q. 29:18-31.

Hammer, J. F., J. M. Morton, and K. L. Kerrisk. 2012. Quarter-milking-, quarter-, udder- and lactation-level risk factors and indicators for clinical mastitis during lactation in pasture-fed dairy cows managed in an automatic milking system. Aust. Vet. J. 90:167-174.

Heikkilä, A.-M., J. I. Nousiainen, and S. Pyörälä. 2012. Costs of clinical mastitis with special reference to premature culling. J. Dairy Sci. 95:139-150.

Heravi Moussavi, A., M. D. Mesgaran, and R. O. Gilbert. 2012. Effect of mastitis during the first lactation on production and reproduction performance of Holstein cows. Trop. Anim. Health Prod. 44:1567-1573

Heringstad, B. Y. M. Chang, I. M. Andersen-Ranberg, and D. Gianola. 2006. Genetic analysis of number of mastitis cases and number of services to conception using a censored threshold model. J. Dairy Sci. 89:4042-4048.

Hertl, J. A., Y. H. Schukken, D. Bar, G. J. Bennett, R. N. González, B. J. Rauch, F. L. Welcome, L. W. Tauer, and Y. T. Gröhn. 2011. The effect of recurrent episodes of clinical mastitis caused by gram-positive and gram-negative bacteria and other organisms on mortality and culling in Holstein dairy cows. J. Dairy Sci. 94:4863-4877.

Hertl, J. A., Y. H. Schukken, F. L. Welcome, L. W. Tauer, and Y. T. Gröhn. 2014. Pathogen-specific effects on milk yield in repeated clinical mastitis episodes in Holstein dairy cows. J. Dairy Sci. 97:1465-1480.

Higgins, J. P., and S. Green, ed. 2011. Cochrane Handbook for Systematic Reviews of Interventions. Version 5.1.0. Accessed Feb. 15 2018. http://handbook.cochrane.org.

Hill, A. E., A. L. Green, B. A. Wagner, and D. A. Dargatz. 2009. Relationship between herd size and annual prevalence of and primary antimicrobial treatments for common diseases on dairy operations in the United States. Prev. Vet. Med. 88:264-277.

Hoe, F. G. H., and P. L. Ruegg. 2005. Relationship between antimicrobial susceptibility of clinical mastitis pathogens and treatment outcome in cows. J. Am. Vet. Med. Assoc. 227:1461-1468.

Hortet, P., and H. Seegers. 1998. Loss in milk yield and related composition changes resulting from clinical mastitis in dairy cows. Prev. Vet. Med. 37:1-20. 
Houben, E. H. P., A. A. Dijkhuizen, J. A. M. Van Arendonk, and R. B. M. Huirne. 1993. Short-and long-term production losses and repeatability of clinical mastitis in dairy cattle. J. Dairy Sci. $76: 2561-2578$.

Houben, E. H. P., R. B. M. Huirne, A. A. Dijkhuizen, and A. R. Kristensen. 1994. Optimal replacement of mastitic cows determined by a hierarchic Markov process. J. Dairy Sci. 77:2975-2993.

International Dairy Federation. 1997. Recommendations for presentation of mastitis-related data: Guidelines for evaluation of the milking process. Bulletin 321. IDF, Brussels, Belgium.

Kossaibati, M. A., M. Hovi, and R. J. Esslemont. 1998. Incidence of clinical mastitis in dairy herds in England. Vet. Rec. 143:649-653.

Kuzma, K., and E. Malinowski. 2001. Some factors affecting mastitis occurrence rate in cows. Bull. Vet. Inst. Pulawy 45:297-305.

Lago, A., S. M. Godden, R. Bey, P. L. Ruegg, and K. Leslie. 2011a. The selective treatment of clinical mastitis based on on-farm culture results: I. Effects on antibiotic use, milk withholding time, and short-term clinical and bacteriological outcomes. J. Dairy Sci. 94:4441-4456.

Lago, A., S. M. Godden, R. Bey, P. L. Ruegg, and K. Leslie. 2011b. The selective treatment of clinical mastitis based on on-farm culture results: II. Effects on lactation performance, including clinical mastitis recurrence, somatic cell count, milk production, and cow survival. J. Dairy Sci. 94:4457-4467.

Lam, T. J. G. M., L. J. Lipman, Y. H. Schukken, W. Gaastra, and A. Brand. 1996. Epidemiological characteristics of bovine clinical mastitis caused by Staphylococcus aureus and Escherichia coli studied by DNA fingerprinting. Am. J. Vet. Res. 57:39-42.

Lescourret, F., J. B. Coulon, and B. Faye. 1995. Predictive model of mastitis occurrence in the dairy cow. J. Dairy Sci. 78:2167-2177.

Mahzoniae, M. R., T. Zahraei-Salehi, E. Karimi, N. Shams, and H. Estaki. 2006. Comprative efficacy of addermint (Mentha spicata) phenylbutazone and dam cream in cattle acute mastitis. [In Persian.] Faslnamah-i Giyahan-i Daruyi 3:15-22.

McDougall, S., D. G. Arthur, M. A. Bryan, J. J. Vermunt, and A. M. Weir. 2007. Clinical and bacteriological response to treatment of clinical mastitis with one of three intramammary antibiotics. N. Z. Vet. J. 55:161-170.

Moher, D., A. Liberati, J. Tetzlaff, and D. G. Altman. 2009. Preferred reporting items for systematic reviews and meta-analyses: The PRISMA statement. Ann. Intern. Med. 151:264-269.

Monti, G., and G. de Jong. 2005. Risk of clinical mastitis within lactation in Dutch dairy cattle. Mastitis in dairy production: Current knowledge and future solutions. Pages $622-626$ in 4 th IDF International Mastitis Conference, June 2005, Maastricht, the Netherlands. H. Hogeveen, ed. Wageningen Academic Publishers, Wageningen, the Netherlands.

Morin, D. E., R. D. Shanks, and G. C. McCoy. 1998. Comparison of antibiotic administration in conjunction with supportive measures versus supportive measures alone for treatment of dairy cows with clinical mastitis. J. Am. Vet. Med. Assoc. 213:676-684.

Nash, D. L., G. W. Rogers, J. B. Cooper, G. L. Hargrove, J. F. Keown, and L. B. Hansen. 2000. Heritability of clinical mastitis incidence and relationships with sire transmitting abilities for somatic cell score, udder type traits, productive life, and protein yield. J. Dairy Sci. 83:2350-2360.

Neijenhuis, F., H. W. Barkema, H. Hogeveen, and J. P. T. M. Noordhuizen. 2001. Relationship between teat-end callosity and occurrence of clinical mastitis. J. Dairy Sci. 84:2664-2672.

O'Connor, A. M., J. M. Sargeant, and C. Wang. 2014. Conducting systematic reviews of intervention questions III: Synthesizing data from intervention studies using meta-analysis. Zoonoses Public Health 61:52-63.

Olde Riekerink, R. G. M., H. W. Barkema, D. F. Kelton, and D. T. Scholl. 2008. Incidence rate of clinical mastitis on Canadian dairy farms. J. Dairy Sci. 91:1366-1377.

Oliveira, L., C. Hulland, and P. L. Ruegg. 2013. Characterization of clinical mastitis occurring in cows on 50 large dairy herds in Wisconsin. J. Dairy Sci. 96:7538-7549.

Pantoja, J. C. F., C. Hulland, and P. L. Ruegg. 2009. Somatic cell count status across the dry period as a risk factor for the develop- ment of clinical mastitis in the subsequent lactation. J. Dairy Sci. 92:139-148.

Peeler, E. J., M. J. Green, J. L. Fitzpatrick, and L. E. Green. 2002. Study of clinical mastitis in British dairy herds with bulk milk somatic cell counts less than 150,000 cells/ml. Vet. Rec. 151:170-176.

Pérez-Cabal, M. A., G. De los Campos, A. I. Vazquez, D. Gianola, G. J. M. Rosa, K. A. Weigel, and R. Alenda. 2009. Genetic evaluation of susceptibility to clinical mastitis in Spanish Holstein cows. J. Dairy Sci. 92:3472-3480.

Petrovski, K. R., M. Trajcev, and G. Buneski. 2006. A review of the factors affecting the costs of bovine mastitis. J. S. Afr. Vet. Assoc. $77: 52-60$

Pinedo, P. J., C. Fleming, and C. A. Risco. 2012. Events occurring during the previous lactation, the dry period, and peripartum as risk factors for early lactation mastitis in cows receiving 2 different intramammary dry cow therapies. J. Dairy Sci. 95:7015-7026.

Pinzón-Sánchez, C., V. E. Cabrera, and P. L. Ruegg. 2011. Decision tree analysis of treatment strategies for mild and moderate cases of clinical mastitis occurring in early lactation. J. Dairy Sci. 94:1873-1892.

Pinzón-Sánchez, C., and P. L. Ruegg. 2011. Risk factors associated with short-term post-treatment outcomes of clinical mastitis. J. Dairy Sci. 94:3397-3410.

Pol, M., and P. L. Ruegg. 2007. Treatment practices and quantification of antimicrobial drug usage in conventional and organic dairy farms in Wisconsin. J. Dairy Sci. 90:249-261.

Rajala, P. J., and Y. T. Gröhn. 1998. Disease occurrence and risk factor analysis in Finnish Ayrshire cows. Acta Vet. Scand. 39:1-13.

Rodrigues-Motta, M., D. Gianola, B. Heringstad, G. J. M. Rosa, and Y. M. Chang. 2007. A zero-inflated Poisson model for genetic analysis of the number of mastitis cases in Norwegian Red cows. J. Dairy Sci. 90:5306-5315.

Ruegg, P. L. 2003. Investigation of mastitis problems on farms. Vet. Clin. North Am. Food Anim. Pract. 19:47-73.

Sæbø, S. 2004. Analyzing survival data on dairy cattle: Some new methods and applications. PhD Diss. Agricultural University of Norway, Oslo.

Saini, V., J. T. McClure, D. Léger, S. Dufour, A. G. Sheldon, D. T. Scholl, and H. W. Barkema. 2012. Antimicrobial use on Canadian dairy farms. J. Dairy Sci. 95:1209-1221.

Schukken, Y. H., D. Bar, J. Hertl, and Y. T. Gröhn. 2010. Correlated time to event data: Modeling repeated clinical mastitis data from dairy cattle in New York State. Prev. Vet. Med. 97:150-156.

Schukken, Y. H., J. Hertl, D. Bar, G. J. Bennett, R. N. González, B. J. Rauch, C. Santisteban, H. F. Schulte, L. Tauer, and F. L. Welcome. 2009. Effects of repeated gram-positive and gram-negative clinical mastitis episodes on milk yield loss in Holstein dairy cows. J. Dairy Sci. 92:3091-3105.

Steeneveld, W., H. Hogeveen, H. W. Barkema, J. van den Broek, and R. B. M. Huirne. 2008. The influence of cow factors on the incidence of clinical mastitis in dairy cows. J. Dairy Sci. 91:1391-1402.

Sviland, S., and S. Waage. 2002. Clinical bovine mastitis in Norway. Prev. Vet. Med. 54:65-78.

Swinkels, J. M., T. J. G. M. Lam, M. J. Green, and A. J. Bradley. 2013. Effect of extended cefquinome treatment on clinical persistence or recurrence of environmental clinical mastitis. Vet. J. 197:682-687.

Tenhagen, B. A., P. Kalbe, G. Klunder, W. Heuwieser, and B. Baumgartner. 1999. Cow specific risk factors for mastitis caused by Prototheca spp. Dtsch. Tierarztl. Wochenschr. 106:376-380.

Trajčev, M., D. Nakov, S. Hristov, S. Andonov, and M. JoksimovicTodorovic. 2013. Clinical mastitis in Macedonian dairy herds. Acta Vet. (Beogr.) 63:63-76.

Trajkovski, T., M. Trajcev, G. Bunevski, and Z. Mazirov. 1997. The udder hygiene of cows in lactation. Mac. Agric. Rev. 44:47-54.

Vaarst, M., and C. Enevoldsen. 1997. Patterns of clinical mastitis manifestations in Danish organic dairy herds. J. Dairy Res. 64:23-37.

Vaarst, M., B. Paarup-Laursen, H. Houe, C. Fossing, and H. J. Andersen. 2002. Farmers' choice of medical treatment of mastitis in Danish dairy herds based on qualitative research interviews. J. Dairy Sci. 85:992-1001. 
van den Borne, B. H. P., G. van Schaik, T. J. G. M. Lam, and M. Nielen. 2010. Variation in herd level mastitis indicators between primiand multiparae in Dutch dairy herds. Prev. Vet. Med. 96:49-55.

Van Eenennaam, A. L., I. A. Gardner, J. Holmes, L. Perani, R. J Anderson, J. S. Cullor, and W. M. Guterbock. 1995. Financial analysis of alternative treatments for clinical mastitis associated with environmental pathogens. J. Dairy Sci. 78:2086-2095.

van Houwelingen, H. C., L. R. Arends, and T. Stijnen. 2002. Advanced methods in meta-analysis: Multivariate approach and meta-regression. Stat. Med. 21:589-624.

Vazquez, A. I., K. A. Weigel, D. Gianola, D. M. Bates, M. A. PérezCabal, G. J. M. Rosa, and Y. M. Chang. 2009. Poisson versus threshold models for genetic analysis of clinical mastitis in US Holsteins. J. Dairy Sci. 92:5239-5247.

Wells, G., B. Shea, D. O'Connell, J. Peterson, V. Welch, M. Losos and P. Tugwell. 2014. The Newcastle-Ottawa Scale (NOS) for assessing the quality of nonrandomised studies in meta-analyses. Accessed Nov. 23, 2017. http://www.ohri.ca/programs/clinical _epidemiology/oxford.asp.

Wenz, J. R., F. B. Garry, J. E. Lombard, R. Elia, D. Prentice, and R. P. Dinsmore. 2005. Efficacy of parenteral ceftiofur for treatment of systemically mild clinical mastitis in dairy cattle. J. Dairy Sci. 88:3496-3499.

Whist, A. C., and O. Østerås. 2007. Associations between somatic cell counts at calving or prior to drying-off and clinical mastitis in the remaining or subsequent lactation. J. Dairy Res. 74:66-73.
Wilson, D. J., R. N. Gonzalez, J. Hertl, H. F. Schulte, G. J. Bennett Y. H. Schukken, and Y. T. Gröhn. 2004. Effect of clinical mastitis on the lactation curve: A mixed model estimation using daily milk weights. J. Dairy Sci. 87:2073-2084.

Wolf, J., M. Wolfová, and M. Štípková. 2010. A model for the genetic evaluation of number of clinical mastitis cases per lactation in Czech Holstein cows. J. Dairy Sci. 93:1193-1204.

Wolfová, M., M. Štípková, and J. Wolf. 2006. Incidence and economics of clinical mastitis in five Holstein herds in the Czech Republic. Prev. Vet. Med. 77:48-64.

Yancey, R. J., M. S. Sanchez, and C. W. Ford. 1991. Activity of antibiotics against Staphylococcus aureus within polymorphonuclear neutrophils. Eur. J. Clin. Microbiol. Infect. Dis. 10:107-113.

Zadoks, R. N., H. G. Allore, H. W. Barkema, O. C. Sampimon, G. J. Wellenberg, Y. T. Gröhn, and Y. H. Schukken. 2001. Cow- and quarter-level risk factors for Streptococcus uberis and Staphylococcus aureus mastitis. J. Dairy Sci. 84:2649-2663.

Zadoks, R. N., B. E. Gillespie, H. W. Barkema, O. C. Sampimon, S. P. Oliver, and Y. H. Schukken. 2003. Clinical, epidemiological and molecular characteristics of Streptococcus uberis infections in dairy herds. Epidemiol. Infect. 130:335-349.

Zoche-Golob, V., and J. Spilke. 2013. Herd-specific estimation of milk yield reduction due to recurrent clinical mastitis. Berl. Munch. Tierarztl. Wochenschr. 126:269-276. 